Int. J. Environ. Sci. Tech.

(C) Spring 2006, Vol. 3, No. 2, pp. 153-157

\title{
The removal of color and COD from wastewater containing water base color by coagulation process
}

\author{
${ }^{*} H$. Asilian, Sh. Moradian fard, A. Rezaei, S. B. Mortazavi and A. Khavanin \\ Department of Occupational and Environmental Health, Faculty of Medical Sciences, Tarbiat Modares University, \\ Tehran, Iran
}

Received 8 January 2006;

revised 12 March 2006;

accepted 20 March 2006;

available online 20 April 2006

\begin{abstract}
In this study acrylic water base color was removed from synthetic wastewater using coagulation process. Experiments were conducted on the sample containing $100 \mathrm{mg} / \mathrm{L}$ and $400 \mathrm{mg} / \mathrm{L}$ of acrylic water base color. Destruction of color by means of coagulation/flocculation techniques using ferrous sulfate, alum, lime and polyelectrolyte (cationic, anionic and non ionic).The study was performed in a systematic approach searching optimum values of alum and $\mathrm{FeSO}_{4}$ concentration, $\mathrm{pH}$ and temperature. All the experiments were run in a laboratory scale. The obtained results show that treatment with alum and ferrous sulfate alone proved to be very effective in removing the color (> $99 \%$ ) and part of COD (60-70\%) from aqueous solution. Lime alone did not significant change on COD and color removal.
\end{abstract}

Key words: Color and COD removal, coagulation, ferrous sulfate, alum, lime, aqueous solution

*Corresponding Author, E-mail: asilianm@yahoo.com

\section{INTRODUCTION}

Water base paint were the earliest type of paint and go to the dawn of history .water born coating have been around in one form or another for decades but have demonstrated greatly improved performance characteristics in recent years Water base or aqueous coating can be divided roughly in to three types. Water-soluble or water- reducible coating are coatings in which a resin in actually dissolved in the water phase. Colloidal or water solubilized dispersion coating are on intermediate between water soluble and emulsion coatings. Latex or emulsion coatings have resins dispersed in water that are stabilized by emulsifiers rather than dissolved. Acrylic paint is a synthetic media made by suspending pigment in synthetic polymer emulsified by water. They are essentially plastic paints that are water soluble and have good adhesive qualities. They are very stable and resist oxidation and chemical decomposition and will not yellow over time. The releas of colore wastewater in the environment is considerable source of non aesthetic pollution and eutrophication and can originate dangerous by products through oxidation; hydrolysis or other chemical reaction taking place in the wastewater phased colorization of dye effluents has therefore received increasing attention. For removal of color pollutants, adsorption on activated carbon, ultrafiltration, reverse osmosis, coagulation by chemical agent, ion exchange on synthetic adsorbent resins, ozonation and advanced oxidation processes $\left(\mathrm{O}_{3} / \mathrm{UV}, \mathrm{H}_{2} \mathrm{O}_{2} / \mathrm{UV}, \mathrm{O}_{3} \mathrm{H}_{2} \mathrm{O}_{2} / \mathrm{UV}, \mathrm{Fe}^{2+} / \mathrm{H}_{2}\right.$ $\mathrm{O}_{2}$ ) can be used. (Azbar et al., 2004 and Kusvuran et al., 2004).

\section{MATERIAL AND METHODS}

\section{Coagulation and flocculation}

Experimental study was designed to obtain maximum $\mathrm{COD}$ and color removal at optimum $\mathrm{pH}$ temperature and $\mathrm{FeSO}_{4}$ and alum doses. Aluminum sulfate $\left(\mathrm{Al}_{2}\left(\mathrm{SO}_{4}\right)_{3} .18\right.$ $\left.\mathrm{H}_{2} \mathrm{O}\right)$ and ferrous sulfate $\left(\mathrm{FeSO}_{4} \cdot 7 \mathrm{H}_{2} \mathrm{O}\right)$ of commercial grade were utilized for the experimental procedure. $\mathrm{A}$ series of jar test experiment after adding coagulants applying 2 min rapid mixing at $120 \mathrm{rpm}, 20$ min slow mixing at $30 \mathrm{rpm}$ and $45 \mathrm{~min}$ settling was conducted by using $500 \mathrm{~mL}$ dye solution. (Georgiou, et al., 2003).

\section{Analytical methods}

COD was measured according to standard methods. Absorbance measurements were made using pu 8700 series uv/vis spectrophotometer for color removal. The 


\section{H. Asilian, et al}

supernatant in each beaker were filtered by $0.45 \mu \mathrm{m}$ millipore membrane filter before measuring COD and absorbance at maximum wave length. Removal efficiency of COD and color were obtained according to the formula given below. (Georgiou, et al., 2003).

Removal $(\%)=\left(\mathrm{c} / \mathrm{c}_{0}\right) / \mathrm{c}_{0}$

Where $c_{0}$ and $c$ are the initial and final absorbance or COD values of simulated wastewater, respectively.

\section{RESULTS}

Coagulation with ferrous sulfate

Basic equations occurring during the coagulation process for ferrous sulfate is given with equation 1 :

$\mathrm{FeSO}_{4}+2 \mathrm{HCO}_{3}^{-} \rightarrow \mathrm{Fe}(\mathrm{OH})_{2}+\mathrm{SO}_{4}^{-2}+2 \mathrm{CO}_{2}$

Varying ferrous sulfate concentration (1000 mg/L) keeping $\mathrm{pH}$ constant (9) were applied for the treatment of wastewater. A ferrous sulfate concentration of 200 $\mathrm{mg} / \mathrm{L}$ and $100 \mathrm{mg} / \mathrm{L}$ was necessary for an efficient COD removal for 400 and $100 \mathrm{mg} / \mathrm{L}$ color concentration and did not significant change COD removal.

\section{Coagulation with aluminum sulfate}

Alumininum ion, $\mathrm{AL}^{+3}$, behaves very much like $\mathrm{Fe}+^{3}$. When alum is added to water or wastewater $\mathrm{AL}(\mathrm{OH})_{3}$ precipitations occurs as described by the following equation 2:

$$
\mathrm{Al}_{2}\left(\mathrm{SO}_{4}\right)_{3}+6 \mathrm{CO}_{3} \longrightarrow 2 \mathrm{AL}(\mathrm{OH})_{3}+3 \mathrm{SO}_{4}^{-2}+6 \mathrm{CO}_{2}(2)
$$

Similar to ferrous sulfate experiment, varing aluminum sulfate concentration, keeping $\mathrm{pH}$ at the optimum condition 10 were applied for the treatment of wastewater. An alum concentration of $600 \mathrm{mg} / \mathrm{L}$ and $300 \mathrm{mg} / \mathrm{L}$ was necessary for an efficient COD removal for 400 and $100 \mathrm{mg} / \mathrm{L}$ color concentration. $\mathrm{Al}_{2}\left(\mathrm{SO}_{4}\right)_{3} 18$ $\mathrm{H}_{2} \mathrm{O}$ and $\mathrm{FeSO}_{4} .7 \mathrm{H}_{2} \mathrm{O}$ coagulant were used during the chemical treatment experimens with varying dosages under varying $\mathrm{pH}$ condition. For comparison the COD and color removal results of under best $\mathrm{pH}$ condition are given in Figs. 1-4 and Table 1.

Table 1: Optimum removal condition for WBA using coagulation process

\begin{tabular}{llll}
\hline WBA Color (mg/L) & & 100 & 400 \\
\hline \multirow{2}{*}{ COD removal (\%) } & Alum & 69 & 70 \\
\multirow{2}{*}{ COLOR removal (\%) } & Ferrous sulfate & 67 & 69 \\
& Alum & 99.8 & 99.99 \\
$\mathrm{pH}$ & Ferrous sulfate & 98.7 & 99.6 \\
& Alum & 10 & 10 \\
$\mathrm{~T}\left({ }^{\circ} \mathrm{C}\right)$ & Ferrous sulfate & 9 & 9 \\
& Alum & 40 & 40 \\
Concentration $(\mathrm{mg} / \mathrm{l})$ & Ferrous sulfate & 30 & 30 \\
& FeSO & 100 & 200 \\
\end{tabular}

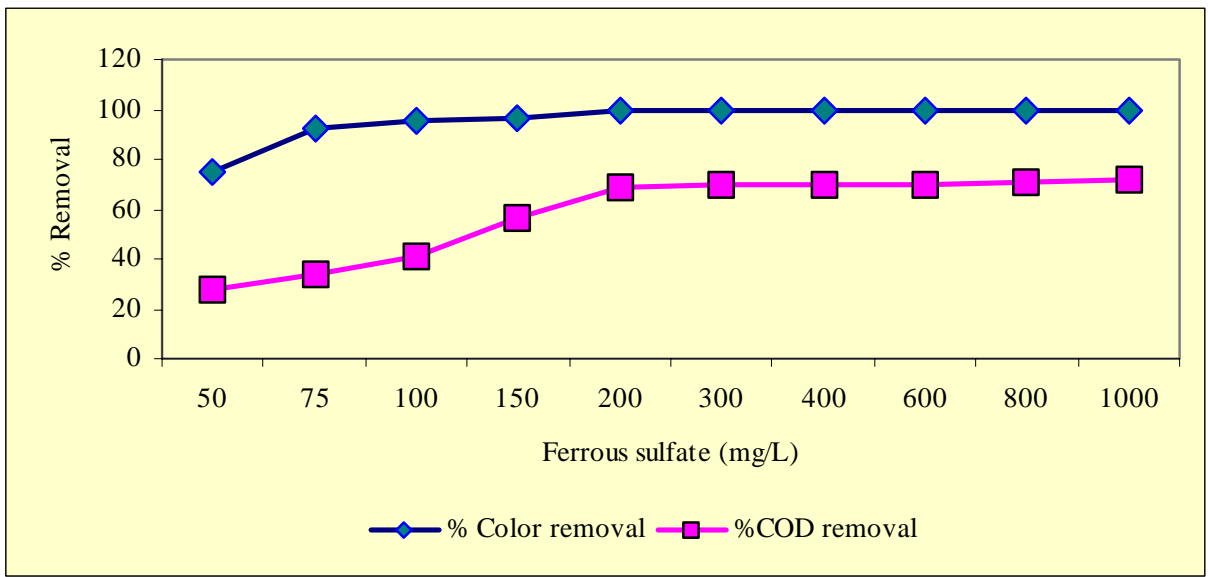

Fig.1: Effect of $\mathrm{FeSO}_{4}$ concentration on COD and color removal $(400 \mathrm{mg} / \mathrm{L} \mathrm{WBA})$ at $9.0 \mathrm{pH}$ 


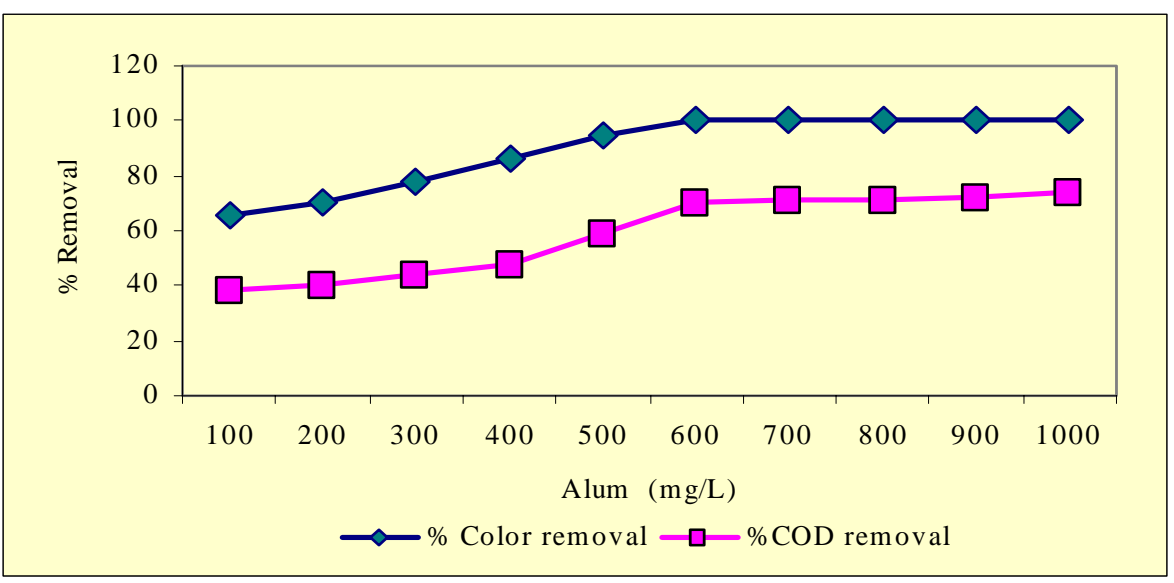

Fig. 2: Effect of Alum concentration on COD and color removal (100 mg/L WBA) at $10.0 \mathrm{pH}$

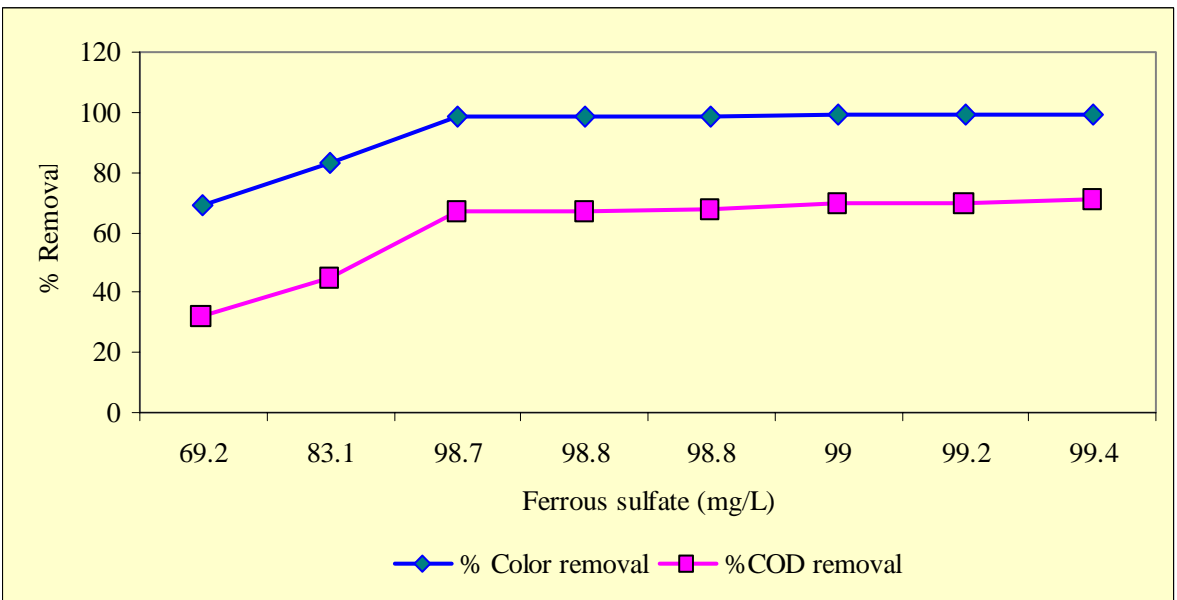

Fig. 3: Effect of $\mathrm{FeSO}_{4}$ concentration on COD and color removal $(100 \mathrm{mg} / \mathrm{L})$ at $9.0 \mathrm{pH}$

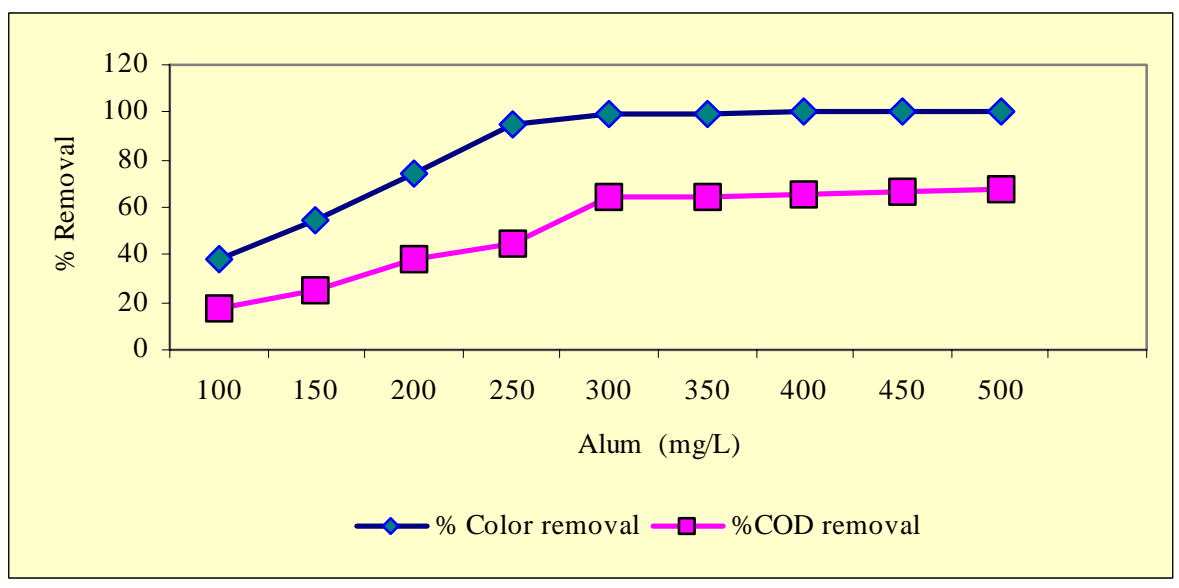

Fig .4: Effect of Alum concentration on COD and color removal (100mg/l WBA) at $10.0 \mathrm{pH}$ 
Optimum $\mathrm{pH}$ and temperature for each coagulant was found to be as follow: $\mathrm{pH}=3, \mathrm{~T}=40$ for alum and $\mathrm{pH}=9, \mathrm{~T}=30$ for $\mathrm{FeSO}_{4} \cdot 7 \mathrm{H}_{2} \mathrm{O}$. In term of COD removal, alum and ferrous sulfate used behaved same from the practical point of view as follow: $70 \%$ COD (COD in effluent $=120 \mathrm{mg} / \mathrm{L}$ ) and $99.99 \%$ color removal were observed in experiments using $\mathrm{Al}_{2}\left(\mathrm{SO}_{4}\right)_{3} 18 \mathrm{H}_{2} \mathrm{O}$ with a dose of $600 \mathrm{mg} / \mathrm{L}$ For $400 \mathrm{mg} / \mathrm{L}$ of WBA, and for 100 $\mathrm{mg} / \mathrm{L}$ WBA $69 \%$ COD (COD in effluent = $124 \mathrm{mg} / \mathrm{L}$ ) and color removal by $\mathrm{Al}_{2}\left(\mathrm{SO}_{4}\right)_{3} .18 \mathrm{H}_{2} \mathrm{O}$ with a dose of $300 \mathrm{mg} / \mathrm{L}$ was $99.8 \%$. While the COD removal at a $\mathrm{FeSO}_{4}$ dose of $200 \mathrm{mg} / \mathrm{L}$ resulted in an effluent COD of $124 \mathrm{mg} / \mathrm{L}$ (69\% COD removal) for $400 \mathrm{mg} / \mathrm{L} \mathrm{WBA}$ and by $100 \mathrm{mg} / \mathrm{L} \mathrm{FeSO}_{4}$ for $100 \mathrm{mg} / \mathrm{L} \mathrm{WBA} \mathrm{67 \%} \mathrm{COD}$ removal (COD in effluent $=132 \mathrm{mg} / \mathrm{L}$ ) were observed. Color removal by lime with a dose of $2000 \mathrm{mg} / \mathrm{L}$ and $1000 \mathrm{mg} / \mathrm{L}$ was $37 \%$ and $15 \%$ for 400 and $100 \mathrm{mg} / \mathrm{L}$ color concentration, respectively. COD removal by lime was very low. By using $10 \mathrm{mg} / \mathrm{L}$ polyelectrolyte (cationic, anionic and non ionic) with alum and ferrous sulfate did not significant change on flocculation and size of floces.

\section{DISCUSSION AND CONCLUSION}

Degradation of acrylic water base color in aqueous solutions by the coagulation process was performed. Color removal by coagulation process by use of alum and ferrous sulfate was $>99 \%$ and COD removal is approximately $70 \%$. But lime was not effective on color and COD removal and polyelectrolyte did not significant change on flocculation. Before treatment wastewater by alum and ferrous sulfate $\mathrm{pH}$ must be adjusted and so alkanity was necessary to coagulation that must be adjusted by lime or calcium carbonate, but in this study alkanity of sample was enough. But due to the high chemical sludge production and increasing of hardness and corrosion it seems coagulation was not applicable for color removal in the wastewater containing color.

\section{ACKNOWLEDGEMENTS}

The authors are most appreciated to the laboratory staff of the Department of Occupational and Environmental Health, Faculty of Medical Sciences, Tarbiat Modarres University.

\section{REFERENCES}

Anamaria, B. A., (2000). Ultra filtration for color removal of tannery dyeing waste waters. J. Desalination, 130, 147157.
Anonymous, SAPHA., AWWA., WPCF., (1998). Standard methods for water and wastewater examination, $20^{\text {th. }}$ Ed.

Azbar, N. and Tonar, T., (2004). Comparison of various advanced oxidation processes and chemical treatment methods for COD and color removal from a polyester and acetate fiber dyeing effluent. J. Chemosphere, 55, 35-43.

Costa, A. P., (2004). Bleaching and photo degradation of textile dyes by $\mathrm{H}_{2} \mathrm{O}_{2}$ and solar or ultraviolet radiation. J. Solar E., 77, 29-35.

Gallely, A. G. and Forster, E.F., (1979). Treatment of industrial effluent, 154-159.

Georgiou, D., Aivazidis, A., Hatiras, J. and Gimouhopoulos, K., (2003). Treatment of cotton textile wastewater using lime and ferrous sulfate. J. Water Res., 37, 2248-2250.

Georgiou, D., and Melidis, P., (2002). Degradation of azoreactive dyes by ultraviolet radiation in the presence of hydrogen peroxide. J. Dyeand Pigm., 52, 69-78.

Kang, S., (2000). Decolonization of textile waste water by photo-fenton oxidation technology. J. Chemosphere, 41, 1287-1294.

Kardag, A. and Saraydin, D., (1998). Removal of some cationic dyes from aqueous solution by Acrylamid/Itaconic acid hydro gel water, air. Soil Poll., 106, 369.

Konstantinou, I., K., (2004). $\mathrm{TiO}_{2}$-assisted photocatalytic degradation of azo dyes in a queous solution: kinetic and mechanistic investigation. A review J. Appl. Catalysis B: Environmental, 49, 1-14.

Kusvuran, E., (2004). Comparison of several advanced oxidation processes for the decolorization of Reactive Red 120 azo dye in aqueous solution. J. Hazard. Mater., 109, 85-93.

Lin, S, H. and Jiang, C., (2003). Fenton oxidation and sequencing batch reactor (SBR) treatment of high-strength semiconductor waste water. J. Desalinat., 154, 107-116.

Liu, S. and Liang, S., (2000). Return sludge employed in enhancement of color removal in the integrally industrial wastewater treatment Plant. J. Water Res., 38, 103-110.

Marcucc, M. and Nosenzo, G., (2001). Treatment and reuse of textile effluents based on new ultrafiltration and other membrane. J. Desalinat., 138, 75-82.

Pala, A., (2002). Color removal from cotton textile industry waste water in an activated sludge system with various additives. J. Water Res., 36, 2920-2925.

Porter, J. J. and Sinder, E., (1979). Biodegradability of textile chemical, J. WPCF., 48 (9), 48-52.

Selcuk, H., (2005). Decolonization and detoxification of textile waste water by ozonation and coagulation processes. J. Dye. Pig., 64, 217-222.

Sostar, S., and Simonic, M., (2000). Waste water treatment after reactive printing, J. Dye. Pig., 24, 147-152.

Sungkpet, A., (2004). Treatment of effluents from textile rinsing, Operations by thermally stable nanofiltration membranes. J. Desalinat., 160, 75-81.

Supalanuttapun, J. K., (2004). Microbial decolorization of reactive azo dyes in a sequential anaerobic-aerobic system. J. Chemical Eng., 99, 169-176.

Sureyya, M., Kaptan, D. and Tugba, O., (2004). Color and COD removal from wastewater containing Reactive Black 5 using fenton's oxidation process. J. Chemosphere, 106, 435-441.

Swaminatan, K., and Sandhya, S., (2003). Decolorizaton and degradation of $\mathrm{H}$-acid and other dyes using ferrous-hydrogen peroxide system, J. Chemosphere, 50, 619-625. 


\section{AUTHOR(S) BIOSKETCHES}

Asillian, H., M.Sc., Ph.D., is an assistant professor in Environmental and Occupational Health Department, Tarbiat Modarres University, Tehran, Iran. Email: asilianm@yahoo.com

Moradian Fard, Sh., M.Sc., student in Environmental and Occupational Health Deptartment, Tarbiat Modarres University, Tehran, Iran. Email: sh_moradianfard@yahoo.com

Rezaee, A., M.Sc., Ph.D., is an assistant professor in Environmental and Occupational Health Department, Tarbiat Modarres University, Tehran, Iran. Email: rezaee@modarres.ac.ir

Mortazavi, S. B., M.Sc., Ph.D., is an associated professor in Environmental and Occupational Health Department, Tarbiat Modarres University, Tehran, Iran. Email: sbmortazavi@yahoo.co.uk

Khavanin, A., M.Sc., Ph.D., is an assistant professor in Environmental and Occupational Health Department, Tarbiat Modarres University, Tehran, Iran. Email: khavanin@modarres.ac.ir

\section{This article should be referenced as follows:}

Asillian, H., Moradian Fard, Sh., Rezaee, A., Mortazavi, S. B. and Khavanin, A., (2006). The removal of color and COD from wastewater containing water base color by coagulation process. Int. J. Environ. Sci. Tech., 3 (2), 153-157. 